\title{
Efficacy of selected biological products on broad mite (Polyphagotarsonemus latus Banks) in sweet pepper
}

\author{
Reny G. Gerona'*, Jesusa C. Jimenez', Esmer V. Avelino', Valeriana P. Justo', \\ Raffy Danggoy ${ }^{3}$, Melba B. Agosto', Bernardita I. Lauro', Melody G. Atanoza', \\ Sandra McDougall ${ }^{4}$ and Valerie Draper ${ }^{4}$
}

\begin{abstract}
Four studies were conducted to evaluate the efficacy of potential alternatives to miticides against the broad mite (Polyphagotarsonemus latus Banks) population on sweet peppers grown under protected and open field cultivation at Visayas State University, Baybay, Leyte and one field study was conducted at USTP, Claveria.

Three of these four comparative studies reported that fruit yield was higher under the protected cropping structures than from the open field cultivation; the other study found no significant yield difference. The miticides: abamectin, dinotefuran and sulfur treatments, consistently resulted in the least damage to the plants in both open field and protected cropping plots and higher marketable yields.

The botanicals: 7-Herb Plus, curry plant, onion, and garlic + chilli pepper extracts, and both brewed and unbrewed vermitea showed less mite damage in peppers than the water control treatments but were not as effective as the miticide treatment in both protected and open cultivation. Neem leaf and garlic extracts had less mite damage than the water control in the protected cropping experiment but not the field experiment. Kakawate extract and the insect fungal pathogen, Metarhizium anisopliae SPW isolate were ineffective against mites.
\end{abstract}

Keywords: Broad mite, sweet pepper, botanicals, Philippines, protected structure, open field

\section{INTRODUCTION}

Broad mite, Polyphagotarsonemus latus (Banks) is a major pest of many vegetables, including sweet pepper (Palevsky et al 2001). Broad mites and other

\footnotetext{
'Visayas State University, Visca, Baybay City, Leyte, Philippines

${ }^{2}$ University Researcher, UP Los Baños

${ }^{3}$ Research Assistant based at UST

${ }^{4}$ NSW Department of Primary Industries, Yanco NSW Australia
}

*Corresponding Author. Address: Department of Pest Management, Visayas State University, Visca, Baybay City, Leyte, 6521-A Philippines; Email: rggerona@yahoo.com DOI: $10.32945 /$ atr39sb6.2017 
pests and diseases significantly limit marketable yield of sweet pepper. Sweet pepper production in the Philippines covers $2,469 \mathrm{ha}$. It is one of the priority vegetable crops in the Southern Philippines, where some varieties can be grown all year. The presence of broad mites on plants is often overlooked until the plant shows damage symptoms, as the mite is small, $0.1-0.3 \mathrm{~mm}$ (Venzon et al 2008). Damage symptoms include deformed and hardened leaves, small deformed fruit and stunted growth.

Acaricides are the main control for managing broad mites in most vegetable crops (Lazarre \& Gerling 1993, Simmons \& Jackson 2000). Pesticides have been beneficial for controlling pests, crop diseases and weeds, but they have also have caused a range of concerns such as pesticide residues in food chain, effects on the non-target organisms and development of pesticide resistance by pests (Insecticide Resistance Action Committee [IRAC] 2008, Van Leeuwen et al 2009). Often there is little economic gain from synthetic pesticide use, especially for small scale farmers. The impact on environmental pollution and health problems (Bhaduri et al 1989) has prompted the use of botanical extracts. Cost and availability of botanical extract pesticides are a consideration. Antonio et al (2014) found that kakawate leaf extract can be a potential natural larvicide. Ujjan and Shahzad (2012) confirmed Metarizhium anisopliae attacks a wide range of arthropods and is effective against the fruit borer of jackfruit (Dela Cruz et al 2013). Venzon et al (2013) found that the lime sulfur restrains broad mite population growth in chilli pepper.

The 7-Herb Plus was found to be effective against insect pests of rice (Alfredo Escasinas, ret. Professor,VSU, personal communication). Curry plant (Murraya koenigii), has been reported for its insecticidal properties against Spodoptera litura larvae (Senrung et al 2014). Thodsare et al (2014) found that M. koenigii oil significantly reduced larval weight gain, pupation and adult emergence of Spilosoma obliqua and S. litura. Sarwar (2015) reported garlic, onion, hot pepper and neem possess pesticidal properties. Attia et al (2011) reported garlic extract applications resulted in high female mortality of two spotted mites. Neem extract (Azadirachta indica) was also found to cause high mortality rates and reduce reproductive capacity of two spotted mites (Miranova \& Khorkhordin 1996).

\section{Characteristics of each botanical}

7-Herb Plus combines extracts from seven plant species, lemongrass (Cymbopogon citratus Stapf), buyo (Piper betle L.), panyawan (Tinosphora rumphii Boerl), garlic (Allium sativum L.), bulb onion (Allium cepa L.), tobacco (Nicotiana tabacum L.) and hot pepper (Capsicum annuum L.), to which soap is added. Vermitea is a water extract from vermicast, containing soluble plant nutrients and plant growth regulators. The Philippines Department of Agriculture has been promoting brewed vermitea (aerated), claiming it more effective than the unbrewed vermitea (Adan Alao, Agriculture Technician LGU Baybay City, Leyte, personal communication). Brewed vermitea requires brewing equipment that most small farmers cannot access.

A range of botanical extracts were investigated in a number of studies to determine their effectiveness in controlling broad mite in sweet pepper crops grown under protected structures and open field cultivation, as part of an Australian Centre 
for International Agricultural Research funded project "Integrated Crop Management (ICM) to enhance vegetable profitability and food security in the southern Philippines and Australia" (ACIAR HORT12/020).

\section{MATERIALS AND METHODS}

In four of the five experiments, identical trials were conducted in both a protective structure cultivation system and in open field cultivation system. An additional trial investigating the efficacy of sulfur, abamectin, Metarhizium and kakawate leaf extract was conducted at a separate location, but without the protective structure plots included.

The experimental design, land preparation, preparation of seedlings, transplanting and fertilizer application, water and weed management and pruning were consistent across these four experiments.

\begin{tabular}{|c|c|c|c|}
\hline Experiment & Treatments & Replications & Application \\
\hline $\begin{array}{l}\text { 7-Herb Plus } \\
\text { and Curry } \\
\text { plant extracts }\end{array}$ & $\begin{array}{l}\mathrm{T} 0=\text { tap water } \\
\mathrm{T} 1=7 \text {-Herb Plus } \\
\text { botanical extract } \\
\mathrm{T} 2=\text { Curry plant leaf } \\
\text { extract } \\
\mathrm{T} 3=\text { abamectin (RR) }\end{array}$ & $\begin{array}{l}3 \text { replications/treatment } \\
40 \text { plants/replicate }\end{array}$ & $\begin{array}{l}\text { Botanical extract, } 350 \mathrm{~mL} \text { per } 16 \mathrm{~L} \\
\text { water. Sprayed twice weekly. } \\
\text { Insecticide (abamectin) } 10 \mathrm{~mL} \text { per } \\
16 \mathrm{~L} \text { water (RR). Sprayed once } \\
\text { weekly }\end{array}$ \\
\hline $\begin{array}{l}\text { Neem leaf, } \\
\text { Garlic, Onion, } \\
\text { and Garlic + } \\
\text { chilli pepper } \\
\text { extracts }\end{array}$ & $\begin{array}{l}\text { T0 }=\text { tap water } \\
T 1=\text { Neem } \\
\text { T2 }=\text { Garlic } \\
\text { T3 }=\text { Garlic }+ \text { Chili } \\
\text { pepper } \\
\text { T4 }=\text { Onion } \\
\text { T5 = abamectin (RR) }\end{array}$ & $\begin{array}{l}3 \text { replications/treatment } \\
36 \text { plants/replicate }\end{array}$ & $\begin{array}{l}\text { Neem } 1 \mathrm{~L} \text { extract per } 5 \mathrm{~L} \text { water. } \\
\text { Garlic } 300 \mathrm{~mL} \text { extract per } 16 \mathrm{~L} \\
\text { water. } \\
\text { Garlic + chilli peppers } 300 \mathrm{ml} \\
\text { extract per } 16 \mathrm{~L} \text { water } \\
\text { Onion } 300 \mathrm{~mL} \text { extract per } 16 \mathrm{~L} \\
\text { water Insecticide (abamectin) } \\
10 \mathrm{~mL} \text { per } 16 \mathrm{~L} \text { water (RR). }\end{array}$ \\
\hline $\begin{array}{l}\text { *Sulfur, } \\
\text { Abamectin, } \\
\text { Metarhizium } \\
\text { Kakawate } \\
\text { leaf extract }\end{array}$ & $\begin{array}{l}\text { T1 }=\text { sulfur } \\
T 2=\text { abamectin } \\
T 3=\text { Metarhizium } \\
\text { T4 = Kakawate leaf } \\
\text { extract } \\
\text { T5 }=\text { Tap water. }\end{array}$ & & $\begin{array}{l}\text { Kakawate extract } 300 \mathrm{~mL} \text { per } 16 \mathrm{~L} \\
\text { water. Sprayed twice weekly. } \\
\text { T1 T2 T3 T5 sprayed once weekly }\end{array}$ \\
\hline $\begin{array}{l}\text { Sulfur, } \\
\text { Abermectin, } \\
\text { Metarhizium } \\
\text { Kakawate } \\
\text { leaf extract }\end{array}$ & $\begin{array}{l}\text { T0 }=\text { Tap water } \\
\text { T1 = Kakawate leaf } \\
\text { extract } \\
\text { T2 = Metarhizium } \\
\text { anisopliae } \\
\text { T3 = sulfur } \\
\text { T4 = abamectin }\end{array}$ & $\begin{array}{l}3 \text { replications/treatment } \\
32 \text { plants/replicate }\end{array}$ & $\begin{array}{l}\text { Kakawate extract } 350 \mathrm{~mL} \text { per } 16 \mathrm{~L} \\
\text { water. } \\
\text { Metarhizium anisopliae (3L per } \\
13 \mathrm{~L} \text { water } \\
\text { Sulfur (5g per } 16 \mathrm{~L} \text { water). } \\
\text { Insecticide abamectin } 10 \mathrm{~mL} \text { per } \\
16 \mathrm{~L} \text { water }\end{array}$ \\
\hline
\end{tabular}


Efficacy of selected biological products on broad mite

\begin{tabular}{|c|c|c|c|}
\hline Experiment & Treatments & Replications & Application \\
\hline $\begin{array}{l}\text { Vermitea } \\
\text { brewed } \\
\text { Vermitea un- } \\
\text { brewed }\end{array}$ & $\begin{array}{l}\text { T0 = Tap water } \\
\text { T1 = Vermitea } \\
\text { T2 = Brewed vermitea } \\
\text { T3 = Insecticide } \\
\text { (dinotefuran, Oshin20 } \\
\text { SG) }\end{array}$ & $\begin{array}{l}3 \text { replications/treatment } \\
40 \text { plants/replicate }\end{array}$ & $\begin{array}{l}\text { Vermitea } 1 \mathrm{~L} \text { per } 10 \mathrm{~L} \text { water } \\
\text { (RR) } \\
\text { Brewed vermitea } 1.5 \mathrm{~L} \text { per } \\
16 \mathrm{~L} \text { water (RR) } \\
\text { Insecticide (dinotefuran, } \\
\text { Oshin20 SG) } 2.5 \mathrm{~g} \text { per } 16 \mathrm{~L} \\
\text { water (RR) }\end{array}$ \\
\hline
\end{tabular}

* No trial conducted under protected cropping structure in this experiment. RR= recommended label rate

\section{Sampling}

Data collected from 10 inner plants per replicate.

\section{Rating of Arthropods Infesting Sweet Pepper}

Ratings were done once a week by examining the leaves, flowers, fruits and stems of ten inner sample plants per replication following the visual rating scale modified from MV Navesero and JP Manipol (2005).

\section{Rating Scale for Broad Mite Damage}

\section{Scale}

1

3

5

7

9

\section{Description}

No visible symptom

Slight: Curling/thickening/stunting appearance of developing leaves

(shoot)

Moderate: Curling/thickening/stunting appearance of developing leaves (shoot) and young fully expanded leaves; bronzing/deformation of less than $25 \%$ of the fruits.

Severe: Curling/thickening/stunting appearance of developing leaves (shoot) and about $50 \%$ of fully expanded leaves; bronzing/deformation of $25-50 \%$ of the fruits.

Very severe: more than $50 \%$ of leaves severely curled/thickened/stunted; bronzing or deformation of more than $50 \%$ of the fruits. 


\section{Harvesting}

Fruit was harvested early in the morning to avoid sun damage. Harvested fruit was sorted into marketable and non-marketable categories. Marketable fruit was mature, free from insect damage, diseases and any mechanical injury and at market standard fruit size. Non-marketable fruit had visible damage from mites and other pests, reduced size or mechanical injuries.

\section{Experimental design}

Four experiments were on laid-out and arranged in Randomized Complete Block Design (RCBD). ANOVA was computed using Star Tool for Agricultural Research (STAR) and means were computed using 5\% LSD. The vermitea experiment was laid-out and arranged in two-factor factorial in RCBD. ANOVA was computed using CROP STAT and means were computed using $5 \%$ LSD.
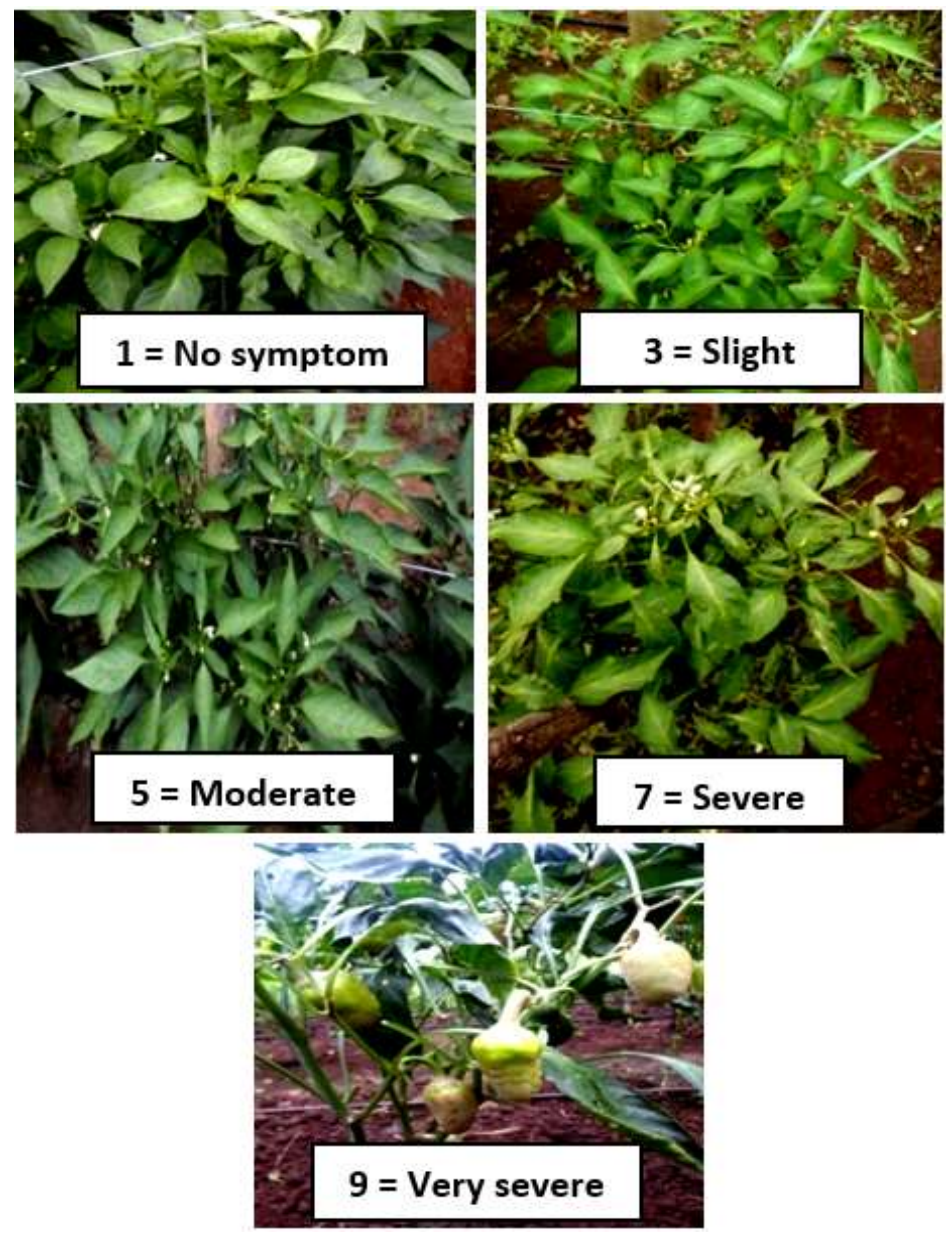
Efficacy of selected biological products on broad mite

\section{RESULTS}

\section{Efficacy of 7-Herb Plus and Curry plant extracts on broad mite}

Ratings in the open field are shown in Figure 1. The inconsistent effect of the treatments, as reflected by the damage ratings, may be the result of the variable weather conditions particularly heavy rains. Whereas in the protected cultivation trial the treatment rankings were far more consistent (Figure 2), probably due to the protection of the treatments from rainfall.

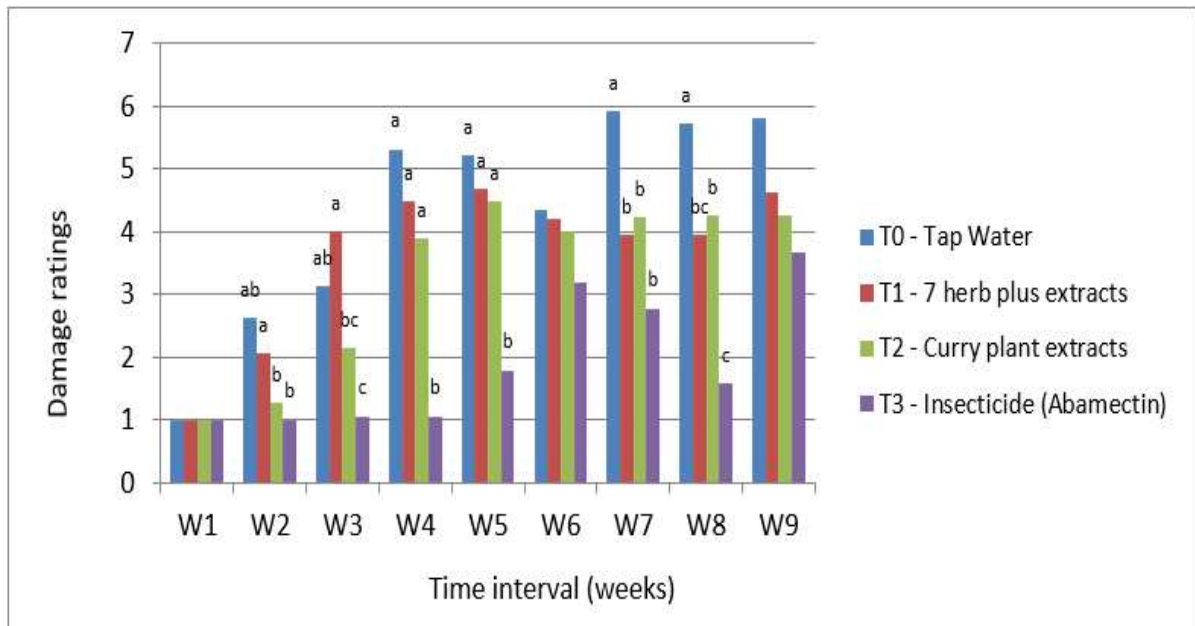

Figure 1. Graphical representation of weekly broad mite damage ratings on sweet pepper grown under open field cultivation

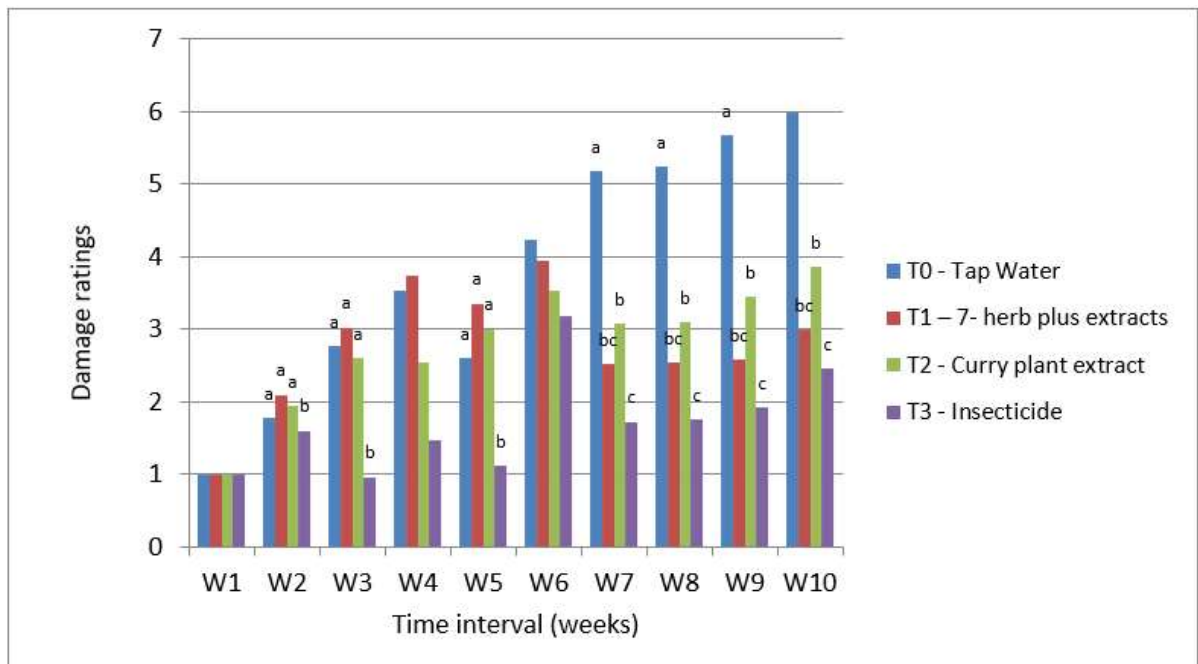

Figure 2. Graphical representation of weekly broad mite damage ratings on sweet pepper grown under protected cultivation 


\section{Effects of the Treatments on the Yield of Sweet Pepper}

The total number and weight of both marketable and non-marketable fruit per treatment harvested from both types of cultivation (Figure 3 ) show that the number and weight of marketable fruit did not differ significantly between treatments within the type of cultivation. However, yields in all treatments were evidently higher under protected cultivation than in open field. This difference in yield was due to the better overall growth and longer reproductive period of the plants under structure than in the open field.

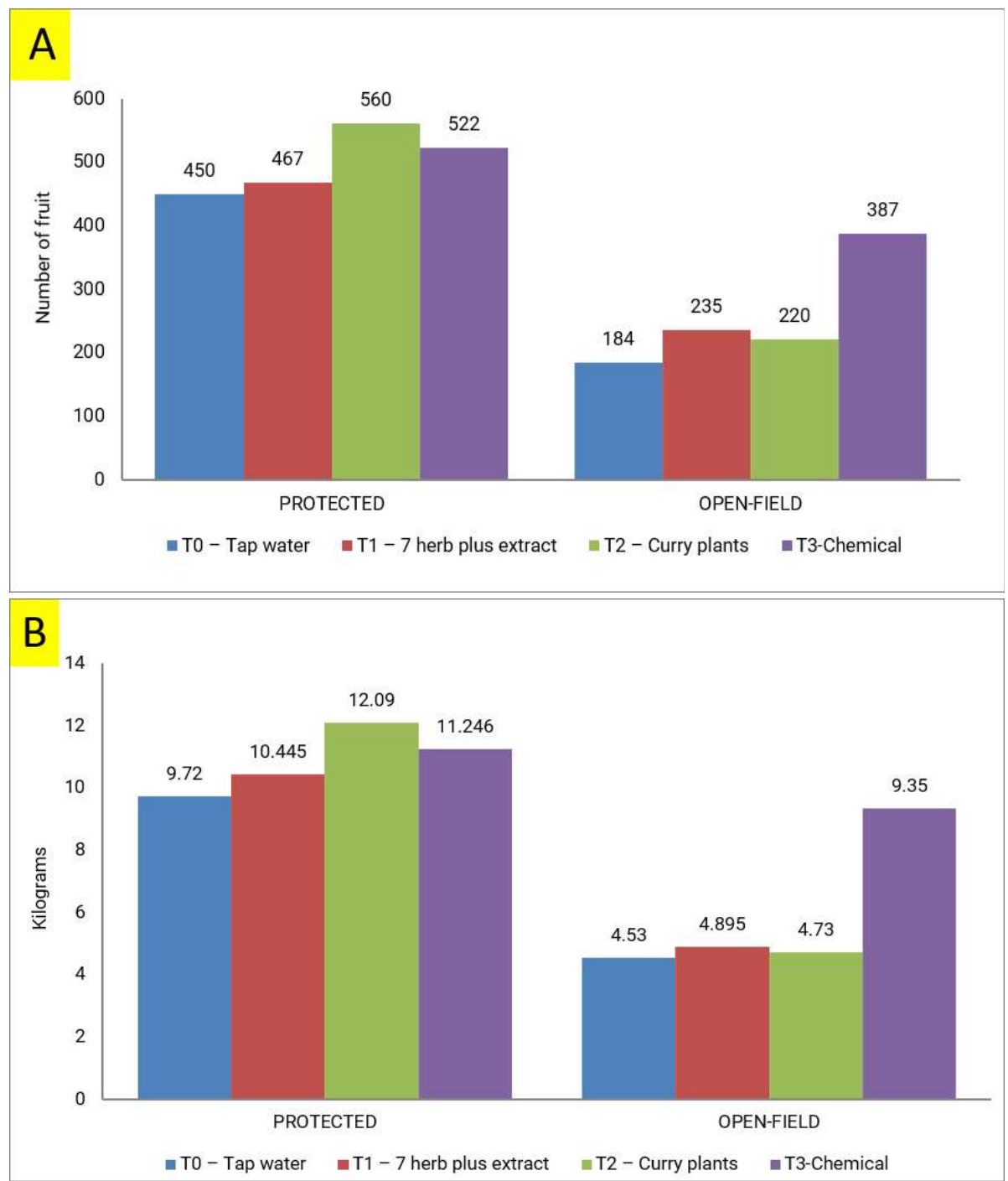

Figure 3. Total number (A) and weight (B) of marketable sweet pepper under protected and open field cultivation 
Efficacy of selected biological products on broad mite

Efficacy of Neem Leaf, Garlic, Onion, and Garlic + Chilli Pepper extracts on Broad mite

The abamectin insecticide treatment, resulted in the lowest broad mite damage ratings and tap water resulted in the highest broad mite damage ratings (Figure 4). Neem, garlic), garlic + hot pepper and onion botanical treatments resulted in significantly lower ratings than those of tap water, especially in the $4^{\text {th }}$ and $5^{\text {th }}$ week ratings under structure. General observation showed that broad mite damage ratings were higher in the open field, although results followed similar trend with those under structure.
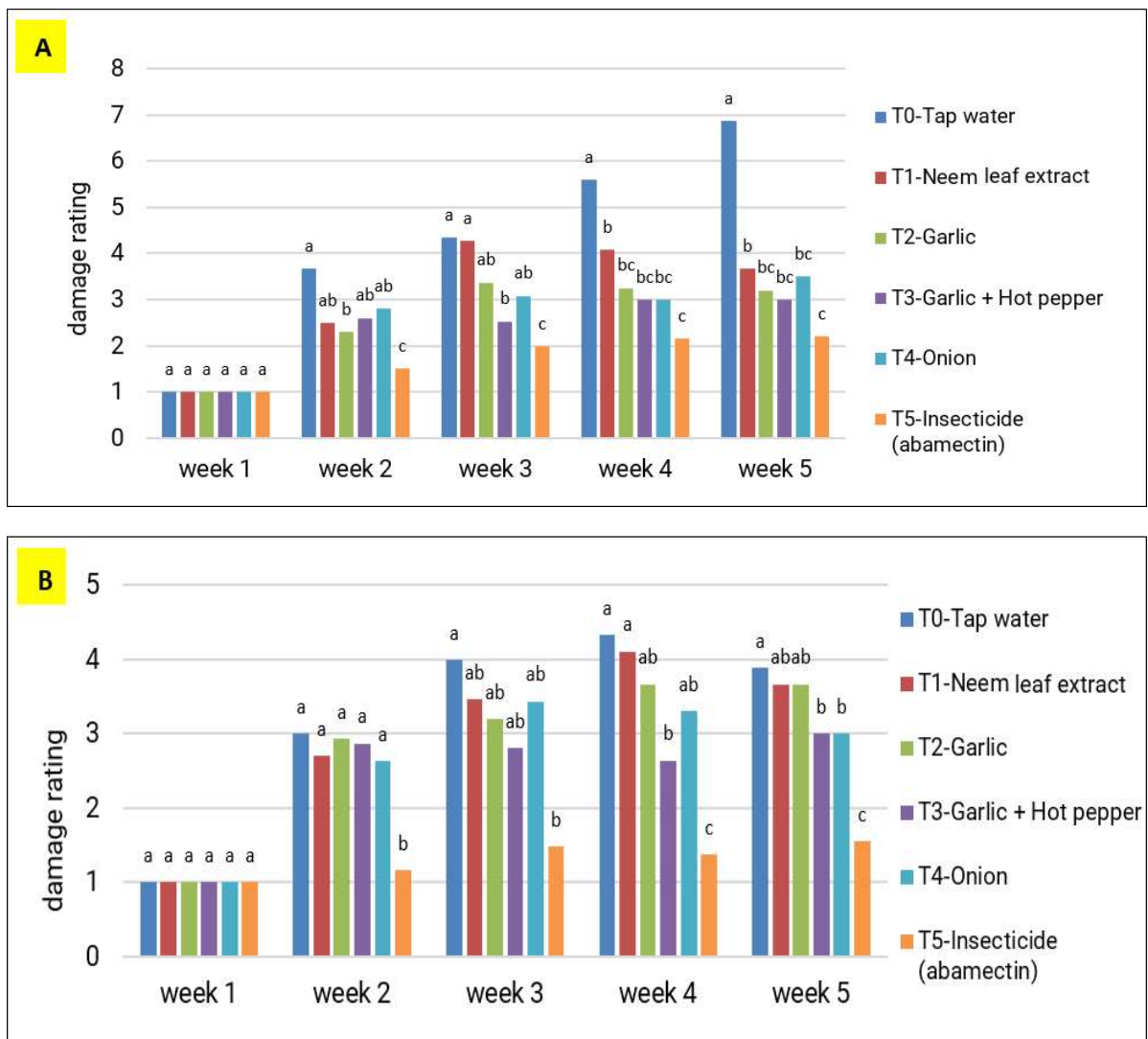

Figure 4. Weekly broad mite damage ratings in protected (A) and open field (B) cultivation

\section{Effects of the Treatments on the Yield of Sweet Pepper}

There was no significant difference on the mean number and weight of marketable fruits of sweet pepper (Figure 5). However, it appeared that yields under structure were generally higher than those in the open field. 
Gerona et al

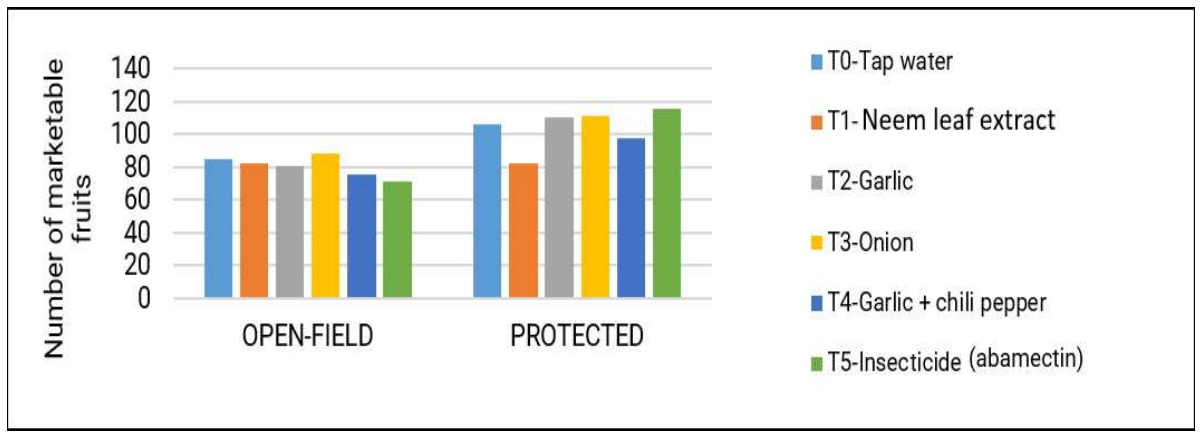

Figure 5. Mean number of marketable fruits per plant under protected and open field cultivation

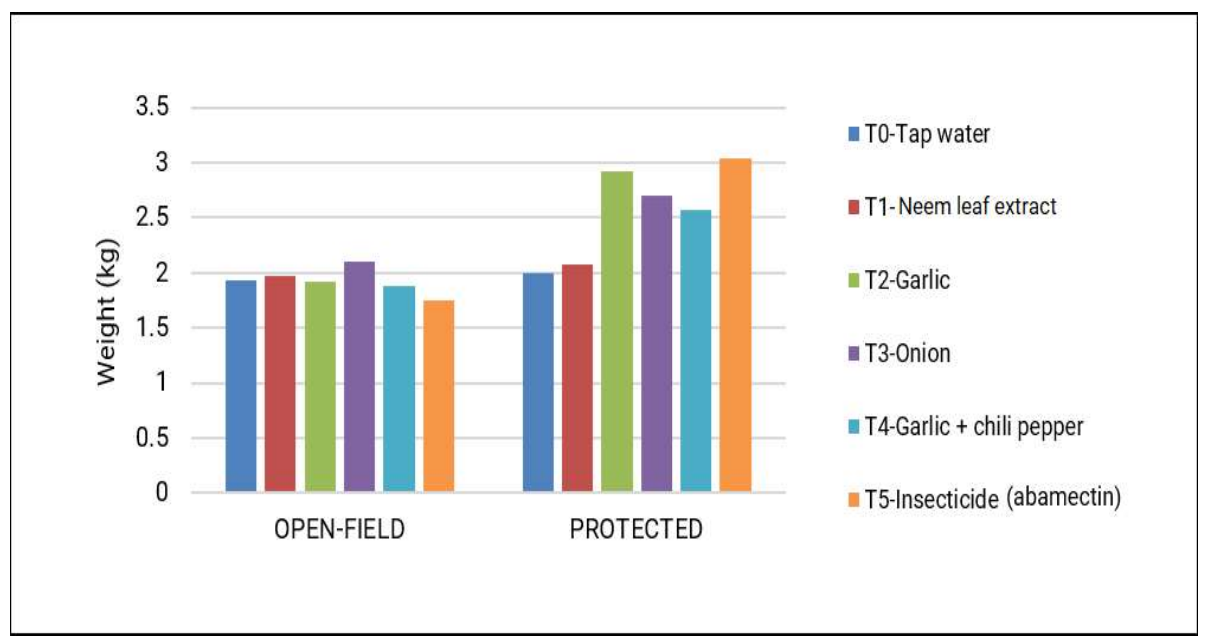

Figure 6. Mean weight of marketable fruit per plant under protected and open field cultivation

\section{Efficacy of sulfur, abamectin, Metarhizium, Kakawate leaf extract on Broad mite (open field)}

Sulfur treated plots showed the least broad mite damage; water treated plots had significantly higher infestation and there were no significant differences observed among the other treatments, abamectin, Metarhizium and kakawate leaf extract. Metarhizium was the next best treatment, the fungal spores and fruiting bodies cover the mites killing them (Figure 7). 
Efficacy of selected biological products on broad mite

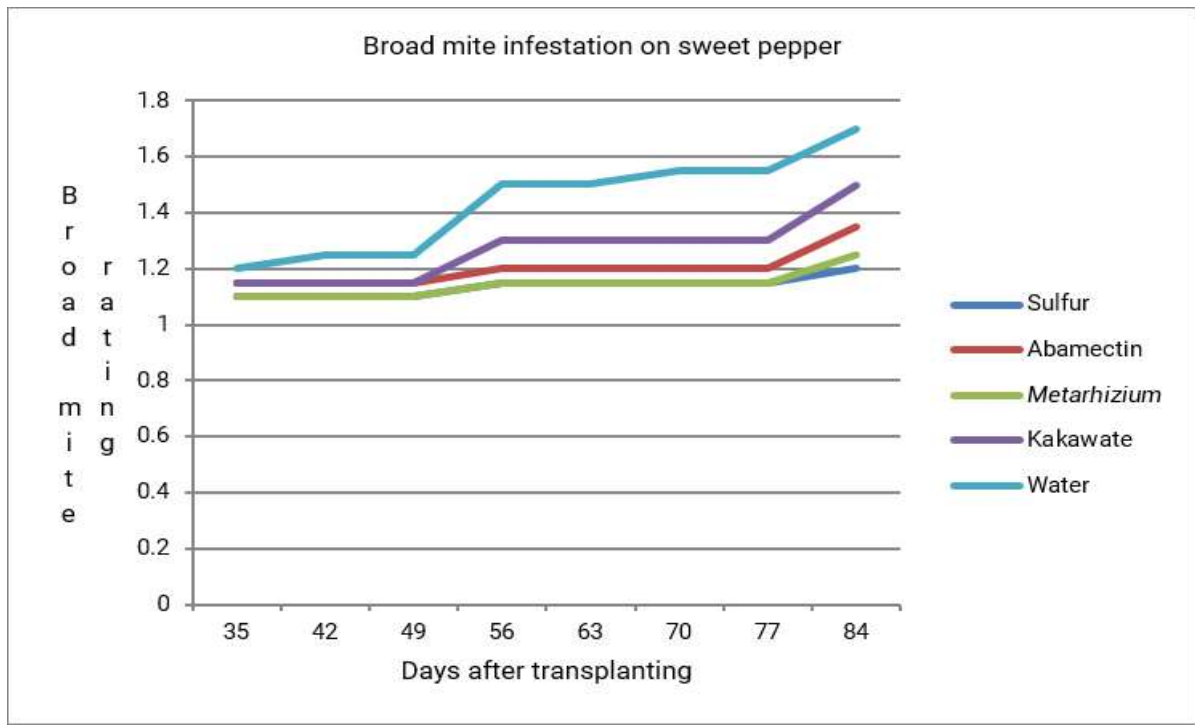

Figure 7. Broad mite damage rating over growing season of sweet pepper grown in Claveria, Misamis Oriental on December 2016-March 2017

\section{Effects of the Treatments on the Yield of Sweet Pepper}

Damaged fruits were $20-30 \%$ of the total non-marketable fruits. The highest yield was obtained from the sulfur treated plants followed by Metarhizium and kakawate (Figure 8). The lowest yield was from the untreated control plots where the plants were sprayed with water only.

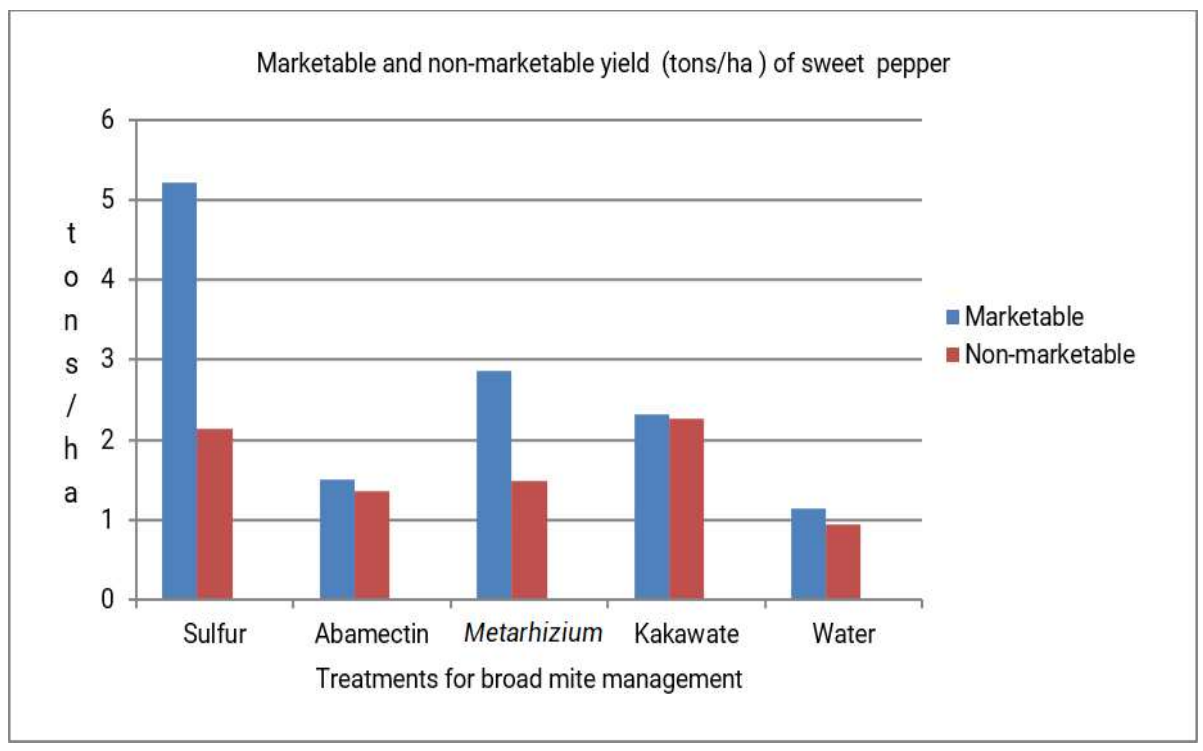

Figure 8. Total, marketable and non-marketable fruits of sweet pepper at USTP, Claveria 
Efficacy of sulfur, abamectin, Metarhizium, kakawate leaf extract on broad mite (open field and protected structure)

Sulfur generally got the lower ratings, which were comparable with abamectin in some weeks. Kakawate and Metarhizium. anisopliae ratings were comparable with tap water. Similar results were obtained under structure (Figure 9B) although treatments have a better effect under structure especially abamectin and sulfur treatments. Results suggested that kakawate and $M$. anisopliae treatments were not effective against the broad mite.
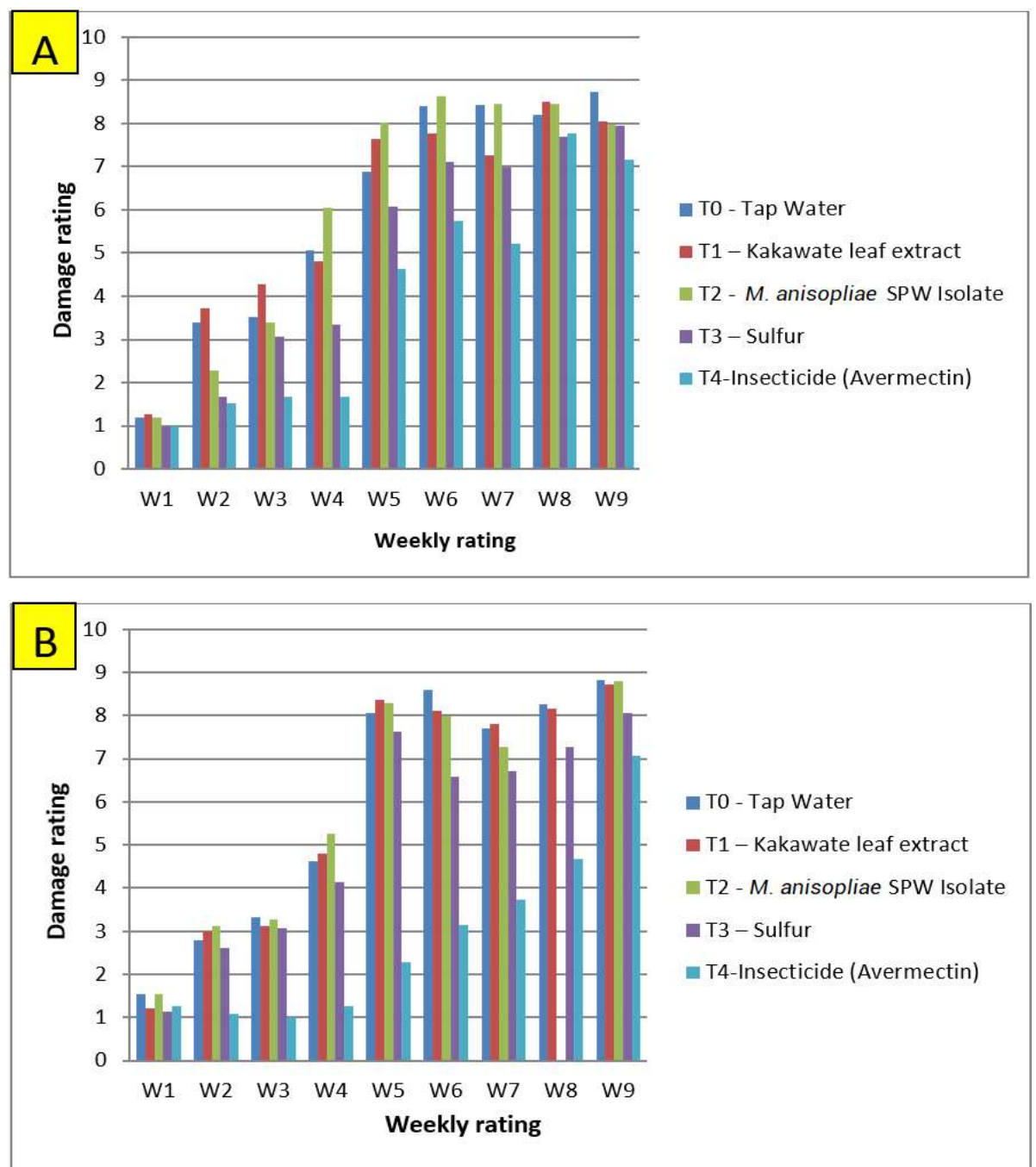

Figure 9. Graphical representation of weekly damage ratings of broad mite in open field $(A)$ and protected (B) cultivation 
Efficacy of selected biological products on broad mite

\section{Effects of the Treatments on the Yield of Sweet Pepper}

Yields of marketable fruit were highest in abamectin treated plots, while other treatments had comparable yields. A similar trend between treatments was observed in open field cultivation, although yields were generally higher under protected structure cultivation (Figure 10). Figure 11 shows very high number and weight of non-marketable fruit among treatments and between cropping systems during the whole cropping season. This was due to the severe mite damage coupled with severe fruit fly damage this season.

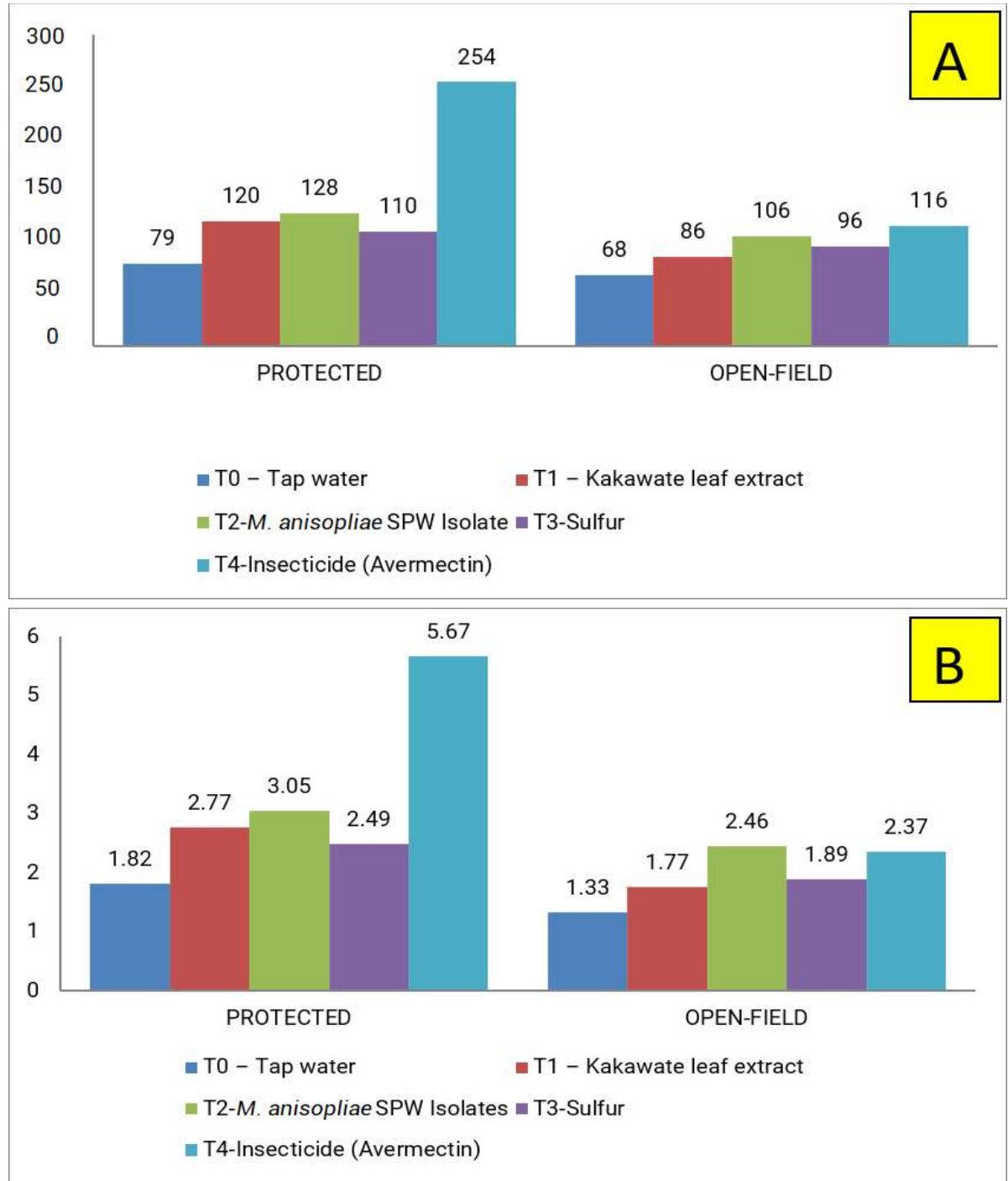

Figure 10. Total marketable number of fruits (A) and weight (B) marketable fruit of sweet pepper under protected and open field cultivation 
Gerona et al
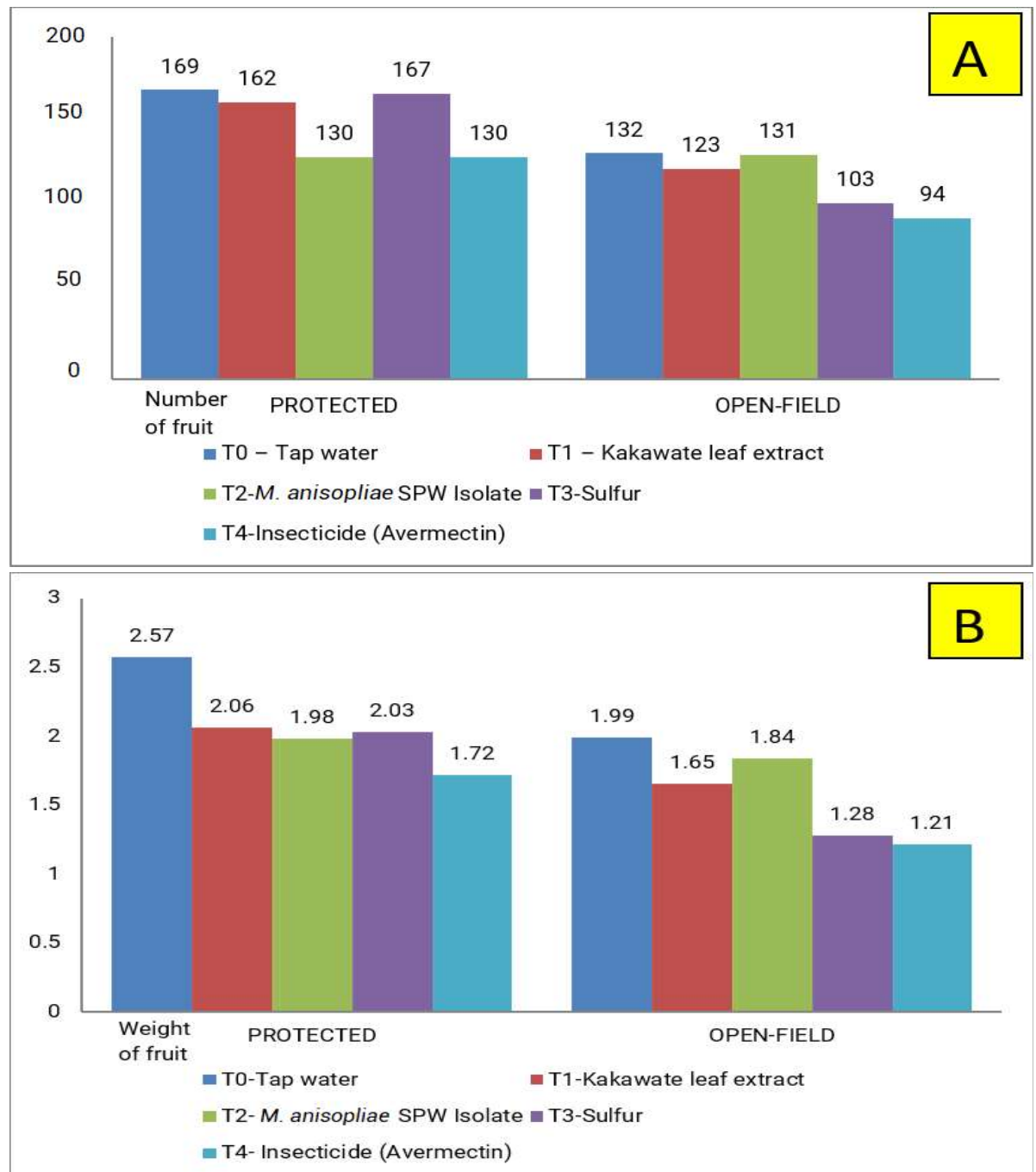

Figure 11. Total non-marketable fruits number (A) and weight (B) of sweet pepper under protected and open field cultivation

\section{Efficacy of vermitea (un-brewed and brewed) Extract on Broad Mite}

\section{Open field cultivation results (Figure 12)}

In all treatments, the initial ratings were generally slight, but became moderate to almost severe through time. Overall damage ratings in the brewed vermitea and and dinotefuran treated plots were lower than damage ratings for un-brewed vermitea and tap water treated plots. In weeks 3, 4, 6, 8, 9 and 10 there were no significant differences in ratings among treatments, which ranged from slight to almost severe. There was $10-20 \mathrm{~mm}$ of rain in weeks 3,4 and 6 ; and $25-30 \mathrm{~mm}$ in weeks 5 and 8 and this impacted the treatments and presence of broad mites. 
Efficacy of selected biological products on broad mite

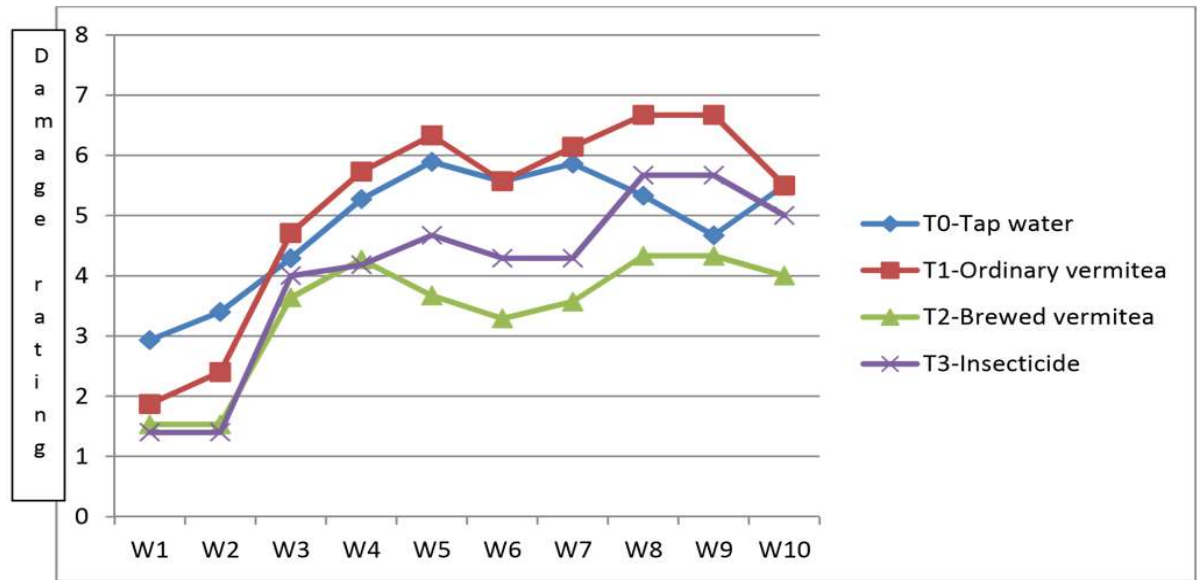

Figure 12. Graphical presentation of broad mite damage ratings taken weekly on sweet pepper under open-field cultivation

\section{Protected structure results (Figure 13)}

Under protected cultivation, rain was prevented from washing off the treatments and the overall trends in the data were similar to those in the open field. Table 1 shows the mean broad mite damage ratings on sweet pepper as affected by the types of cultivation and the different treatments used. Data revealed that brewed vermitea consistently gave low damage ratings of 1.25 and 1.78 under protected and open-field cultivation, respectively, which was comparable to dinotefuran (1.72) under protected structure cultivation, but much lower than dinotefuran under open field cultivation. The ratings in brewed vermitea plots were significantly lower than those in un-brewed vermitea plots with 4.04 and 2.51 under protected cultivation and open-field, respectively. The results suggested that brewed vermitea was better than un-brewed vermitea in suppressing broad mite damage in sweet pepper, and was as effective as dinotefuran used under both type of cultivation.

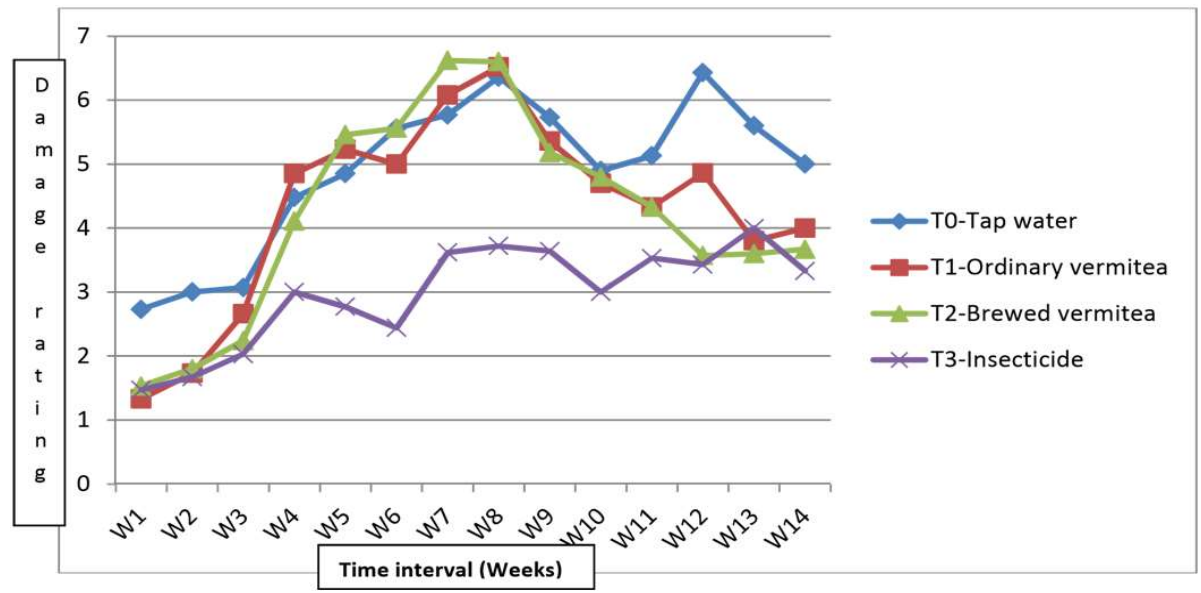

Figure 13. Graphical presentation of the broad mite damage ratings taken weekly on sweet pepper under protected cultivation 
Gerona et al

Table 1. Broad mite ratings taken weekly on sweet pepper under open-field cultivation as affected by different treatment

\begin{tabular}{|c|c|c|c|c|c|c|c|c|c|c|}
\hline \multirow{2}{*}{ Treatments } & \multicolumn{10}{|c|}{ Weekly average damange ratings } \\
\hline & $W_{1}$ & $W_{2}$ & $W_{3}$ & $W_{4}$ & $W_{5}$ & $W_{6}$ & $W_{7}$ & $W_{8}$ & W9 & $W_{10}$ \\
\hline To- Tap water & $2.93^{a}$ & $3.40^{\mathrm{a}}$ & 4.29 & 5.27 & $5.89^{\mathrm{ab}}$ & 5.57 & $5.86^{\mathrm{ab}}$ & 5.33 & 4.67 & 5.50 \\
\hline $\begin{array}{l}\mathrm{T}_{1} \text { - Ordinary } \\
\text { vermitea }\end{array}$ & $1.87^{b}$ & $2.40^{\mathrm{b}}$ & 4.71 & 5.73 & $6.33^{\mathrm{a}}$ & 5.57 & $6.14^{\mathrm{a}}$ & 6.67 & 6.67 & 5.50 \\
\hline $\begin{array}{l}\mathrm{T}_{2} \text { - Brewed } \\
\text { vermitea }\end{array}$ & $1.53^{b}$ & $1.53^{c}$ & 3.64 & 4.27 & $3.67^{c}$ & 3.29 & $3.57^{c}$ & 4.33 & 4.33 & 4.00 \\
\hline $\mathrm{T}_{3}$ - Insecticide & $1.40^{\mathrm{b}}$ & $1.40^{c}$ & 4.00 & 4.18 & $4.67^{\mathrm{bc}}$ & 4.29 & $4.29^{c}$ & 5.67 & 5.67 & 5.00 \\
\hline
\end{tabular}

Average damage ratings from 10 plants/treatment/with three replications; Means having common letters are not significantly different from each other using the comparison of means by Least Significant Difference (LSD) at $5 \%$ level of significance.

Table 2. Weekly broad mite damage ratings on sweet pepper under protected cultivation as affected by different treatments

\begin{tabular}{|c|c|c|c|c|c|c|c|c|c|c|c|c|c|c|}
\hline \multirow{2}{*}{ Treatments } & \multicolumn{14}{|c|}{ Weekly average damage ratings } \\
\hline & $W_{1}$ & $W_{2}$ & $W_{3}$ & $\mathrm{~W}_{4}$ & $W_{5}$ & $W_{6}$ & $W_{7}$ & $W_{8}$ & $W_{9}$ & $W_{10}$ & $W_{11}$ & $W_{12}$ & $W_{13}$ & $W_{14}$ \\
\hline $\mathrm{T}_{0}$ - Tap water & $2.73^{a}$ & $3.00^{\mathrm{a}}$ & $3.07^{\mathrm{a}}$ & $4.48^{a}$ & $4.85^{\mathrm{a}}$ & $5.56^{a}$ & $5.77^{b}$ & $6.36^{a}$ & $5.73^{\mathrm{a}}$ & $4.90^{\mathrm{a}}$ & $5.13^{a}$ & $6.43^{a}$ & $5.6^{a}$ & 5.00 \\
\hline $\begin{array}{l}\mathrm{T}_{1} \text { - Ordinary } \\
\text { vermitea }\end{array}$ & $1.33^{b}$ & $1.73^{b}$ & $2.66^{b}$ & $4.85^{\mathrm{a}}$ & $5.23^{a}$ & $5.00^{\mathrm{a}}$ & $6.08^{a}$ & $6.52^{\mathrm{a}}$ & $5.36^{a}$ & $4.70^{\mathrm{a}}$ & $4.33^{\mathrm{ab}}$ & $4.86^{b}$ & $3.80^{b}$ & 4.00 \\
\hline $\begin{array}{l}\mathrm{T}_{2} \text { - Brewed } \\
\text { vermitea }\end{array}$ & $1.53^{b}$ & $1.80^{b}$ & $2.24^{b}$ & $4.11^{\mathrm{ab}}$ & $5.46^{\mathrm{a}}$ & $5.56^{a}$ & $6.62^{\mathrm{a}}$ & $6.60^{\mathrm{a}}$ & $4.80^{\mathrm{a}}$ & $4.80^{\mathrm{a}}$ & $4.33^{a b}$ & $3.57^{c}$ & $3.60^{b}$ & 3.67 \\
\hline $\begin{array}{l}\mathrm{T}_{3^{-}} \\
\text {Insecticide }\end{array}$ & $1.47^{b}$ & $1.67^{\mathrm{b}}$ & $2.03^{b}$ & $3.00^{b}$ & $2.77^{b}$ & $2.44^{b}$ & $3.72^{b}$ & $3.72^{b}$ & $3.30^{b}$ & $3.30^{\mathrm{b}}$ & $3.53^{b}$ & $3.43^{c}$ & $4.00^{b}$ & 3.33 \\
\hline
\end{tabular}

\section{Effects of the Treatments on the Yield of Sweet Pepper}

However, the observed differences in damage did not translate in to a yield difference. In the open field cultivation, the differences in the number and weight of marketable and non-marketable fruit were not significant between treatments. In the protected structure cultivation, the number and weight of marketable fruits in dinotefuran plots were significantly higher than those in the other treatments. However, there were no significant differences on the number and weight of nonmarketable fruits.

The non-significant difference between treatments in the yield of sweet pepper among treatments in the open-field was probably due to rain affecting the efficacy of the foliar sprays. Under protected cultivation, the use of dinotefuran consistently resulted in lower broad mite damage ratings and a significantly higher yield than the other treatments. Despite the overall average broad mite damage rating being similarly low in the brewed vermitea treatment, the yield results were no different from the water sprayed control. Yield data is less subjective than damage rating and is more important to farmers. 
Efficacy of selected biological products on broad mite

\section{DISCUSSION}

Generally, the plants that were grown under protective structure had a better crop stand than those grown in the open field. In addition, the fruiting period generally lasted a little longer than those planted in the open field. Another considerable difference between the two cultivation systems was a greater incidence of bacterial wilt caused by Ralstonia solanacearum, and weeds in the open field system than in the protective structure cultivation. As a result of these factors the yield of sweet peppers exposed to all mite treatments was greater under protected cultivation than open field. Curry leaf and 7-Herb Plus extracts had less mite damage than the tap water application, but the plants applied with the insecticide abamectin were rated as having least damage. Similarly, neem leaf, garlic, onion, and garlic + chilli pepper extracts resulted in lower damage ratings than tap water applications, and again the insecticide abamectin scored the lowest damage ratings.

One of the components of the 7-Herb Plus extract is tobacco leaf. Scientists at the U.S. Department of Agriculture in the early 1990s found the sugar esters occurring naturally in the foliage of wild tobacco could damage certain soft-bodied insects and mites. The feeding and oviposition by two-spotted spider mite was found to be deterred in trials completed by Neal et al. However, because of the extreme toxicity of pure nicotine to mammals and its rapid absorption into human skin its popularity is diminishing (Isman 2006). Neem has been reported to be most effective against actively growing immature insects (Buss \& Brown 2002). Its effectiveness appears to be affected by the host plant, the insect species and weather conditions. (Lowery et al 1993). Its slow action, high cost of the refined product and irregular antifeeding feature are restrictions to its popularity (Isman 2006).

Garlic was analysed in a series of greenhouse experiments determining the effect of commercially available plant-derived essential oil products on arthropod pests. The product containing garlic was found to cause a mortality rate of $\geq 90 \%$ of two-spotted spider mite. The research highlighted the variability of effectiveness of commercially available plant-derived essential oil products against certain arthropod pests. The detrimental effect of phytotoxicity damage to flowers by products containing garlic was also emphasized.

Chili, garlic and onion extracts had similar effects in this trial. The active component in chili is capsaicin, which destroys cells by stopping the production of certain neurotransmitters that enable cellular communication (Sarwar 2015). Sarwar (2015) referred to the toxicity of capsaicin in high concentrations damaging small wax moth larvae, although there is little published evidence confirming the efficacy of chili as an insecticide. Onions (Allium cepa) are known for their insecticidal, repellent, fungicidal and antiviral properties and a combination of garlic-onion-pepper extract was reported as a potential botanical insecticide in an integrated pest management program to control the thrips, Frankliniella occidentalis, in strawberry production (Kiani et al 2012). However, given thrips, including Frankliniella occidentalis and Thrips tabaci are serious invertebrate pests of onions (Herron et al 2008) their repellancy or insecticidal properties are questionable. 
The two trials investigating the efficacy of sulfur, Metarhizium, abamectin and kakawate reported little variation amongst Metarhizium, abamectin and kakawate extract treatments, however broad mite infestation was significantly lower on sulfur-treated plants and highest on the tap water plots. Marketable yield was significantly higher in the sulfur-treated plots, followed by Metarhizium whereas the water sprayed plots had the lowest yield. Mite infestation was low because of the cool and rainy conditions experienced during the trial period. Sulfur treatment was comparable to abamectin treatment in some weeks of the second trial which compared treatments in open field and protected structure cultivation systems. Regardless of the treatment, the yields of sweet pepper were generally higher under protected cultivation compared with open field.

Entomopathogenic fungi, such as Metarhizium anisopliae SPW isolate, can be considered as potential alternatives for chemical pesticides in certain situations. Further research is needed to improve their efficacy, especially their interaction with the environment and target pest. The potential problems associated with the production of harmful mycotoxins (Vey et al 2001) also require more research with the increasing revelation of the extent of endophytic activity by entomopathogenic fungi.

Neither brewed nor un-brewed vermitea had any effect on mite populations or yields for peppers grown in the open field nor did dinotefuran insecticide. However, for peppers grown under protected cropping, dinotefuran insecticide minimised yield loss from broad mites relative to the vermitea treatments and the water control. Brewed vermitea appeared to have significantly reduced broad mite damage when comparing the sum of each weekly rating relative to the un-brewed vermitea and the water control; but the yield data did not support this observation. Yields of peppers were higher under protective structure than in the open field, regardless of the treatments used.

Dinotefuran (N-methyl-N'-nitro-N" -((tetrahydro-3-furanyl) methyl) guanidine) has been reviewed and classified (pmep.cce.cornell.edu, 2017) as not very acutely toxic, irritating or a skin sensitizer in laboratory animal studies, and it did not demonstrate developmental toxicity, genotoxicity or carcinogenicity, and the United States Environmental Protection Agency (USEPA) classified it as "not likely to be a human carcinogen." It has the potential to cause some neurotoxic, immunotoxic and reproductive effects. Its mode of action as an insecticide is as an agonist of insect nicotinic acetylcholine receptors and it is highly toxic to honeybees and silkworms (Mitsui Chemicals America Inc. 2017).

Sulfur is a non-systemic contact and protectant fungicide with secondary acaricidal activity. Its mode of action as a fungicide is to disrupt the metabolic functioning of fungi. Sulfur is known to be of low toxicity, poses very little if any risk to human and animal health and is categorised as "least toxic", EPA Toxicity Category IV by the USEPA (pmep.cce.cornell.edu 2017). Sulfur is non-toxic to bees and little hazard is expected to occur to non-target organisms when exposed to sulfur.

Abamectin is a mixture of abermectins, insecticidal compounds derived from the soil bacterium Streptomyces avermitilis. Its mode of action is to interfere with neural and neuromuscular transmission of insects. Abamectin is highly toxic to bees, but rapid degradation of abamectin will reduce the risk of bee deaths. If used at recommended application rates, earthworms will not be adversely affected (pmep.cce.cornell.edu 2017). 
Efficacy of selected biological products on broad mite

The availability of plants that have insecticidal properties, local knowledge and traditional cultural practices, combined with the difficulty of enforcing pesticide regulations enhances the potential role of botanicals in food production in developing countries (Isman 2008). However, lack of specificity of botanical products is identified as an impediment to their use. Often a wide range of insect pests are targeted with non-selective botanicals (Kareru et al 2013). Isman (2006) highlights the problems associated with the lack of standardisation of botanical extracts, leading to variation in the concentrate and effect of the final product. A range of insects will react in different ways to the same spray, causing effectiveness variability across products. Neem oil works well against caterpillars, as did a formulated azadiractin (active component of Neem) against aphids (Buss \& Brown 2002). Isman (2006) discusses the low residual effect of botanical extracts and lack of persistence of botanical extracts, which promote and impede their marketability, respectively.

Similarly, vermitea has duplex properties. It has been shown to suppress soilborne diseases, yet if precaution is not taken to ensure the earthworm castings are pathogen-free, it can also be a habitat for soil-borne pathogens. Liu et al (2012) reported an incidence of Phytophthora capsici and several Pythium species occurring in potting mix used on organic farms.

\section{CONCLUSION}

Sulfur was the only product that was as effective as the miticide, abamectin in reducing broad mites in sweet pepper and increasing yields relative to the unsprayed control. Dinoteferan, a neonicitinoid insecticide is not widely registered for mites internationally, but in the one experiment it was included in, it had the highest yields although its' reduction in mite damage was similar to the brewed vermitea. Almost all of the botanical extracts (7-Herb Plus, curry plant leaf, neem leaf, garlic, onion, garlic and chili) evaluated and the brewed vermitea gave reduced broad mite damage relative to the water control under protective cropping, and all except neem in the open field. None were as effective as the commercially formulated miticides. Metarhizium anisopliae SPW isolate and kakawate showed no effect on broad mite populations. Protective cropping gave the best yields even without any mite control. Botanical concoctions based on food plants such as onion, garlic and chilli are low risk to farmers or consumers and may provide some assistance in managing broad mites in sweet pepper. Other botanicals need to have human safety assessments prior to recommending them for use. The 7-herb Plus concoction is concerning with the inclusion of tobacco as an ingredient and is not recommended for farmers to use. Vermi-teas and any fermented concoctions should be assessed for potential for contamination by organisms of food safety concern if sprayed on the harvestable product, ie, sweet pepper fruit. 
Gerona et al

\section{REFERENCES}

Attia SK, Grissa L, Mailleux AC, Lognay G, Heuskin S \& Mayoufi S. 2011. Effective concentrations of garlic distillate (Allium sativum) for the control of Tetranychus urticae Koch. (Tetranychidae). Journal of Applied Entomology 136: $302-312$

Antonio. 2014. Larvicidal effect of Madre de cacao (Gliricidia sepium) leaf extract on household mosquito (Culex pipiens) (Undergraduate thesis)

Bhaduri N, Gupta DP \& Ram S. 1989. Effect of vegetable oils on theovipositional behaviour of Callosobruchus chinensis Fab. Proceedings of 2nd International. Symposium on Bruchids and Legumes (ISBL-2) (pp81-84). Okayama, Japan

Buss $E$ and Brown S. 2002. Natural products for managing landscape and garden pests in Florida. University of Florida, IFAS Extension

Cloyd RA, Galle CL, Keith SR, Kalscheur NA \& Kemp KE. 2009. Effect of commercially available plant-derived essential oil products on arthropod pests. Journal of Economic Entomology 102:1567-1579

Dela Cruz CS, Gapasin RM, Gerona RG, Almeroda BB, Tisado MSP \& Agres MBL. 2013. Biological control of jackfruit fruit borer using a friendly fungus, Metarhizium anisopliae SPW isolate. PCAARRD Info Bull 34:11

Herron GA, James TM, Rophail J \& Mo J. 2008. Australian populations of onion thrips, Thrips tabaci Lindeman (Thysanoptera: Thripidae), are resistant to some insecticides used for their control. Austral Entomology 47(4):361-364

Insecticide Resistance Action Committee (IRAC). 2008. Resistance Management for Sustainable Agriculture and Improved Public Health. IRAC International. http://www.irac-online.org/(viewed 4th October 2017)

Isman MB. 2006. Botanical insecticides, deterrents, and repellents in modern agriculture and an increasingly regulated world. Annual Review of Entomology $51: 45-66$

Isman MB. 2008. Botanical insecticides: for richer, for poorer. Pest Management Science 64: 8-11

Kareru Rotich PZ and MAINA E. 2013. Use of botanicals and safer insecticides designed in controlling insects: the African case. IntechOpen. http://cdn.intechopen.com/pdfs-wm/42222.pdf (accessed 19/9/2016)

Kiani L, Yazdanian M,tafaghodinia B \& Sarayloo MH. 2012. Control of western flower thrips, Frankliniella occidentalis (Pergande) (Thysanoptera: Thripidae), by plant extracts on strawberry in greenhouse conditions. Munis Entomology \& Zoology 7: 857-866

Lazarre M and Gerling D. 1993. The population dynamics of natural enemies of Bemisia tabaci in cotton fields and the influence of insecticide spray. Phytoparasitica 21:171-172

Liu Roos BD, Buttler S, Richter B \& Louws FJ. 2012. Vegetable seedling diseases associated with earthworm castings contaminated with Phytophthora capsici and Pythium attrantheridium. Plant Health Progress

Lowery DT, Isman MB \& Brard NL. 1993. Laboratory and field-evaluation of neem for the control of aphids (Homoptera, Aphididae). Journal of Economic Entomology 86:864-870

Miranova MK and Khorkhordin EG. 1996. Effect of Neem Azal T/S on Tetranychus urticae Koch. Proceedings at the 5th Workshop (pp22-25) 
Efficacy of selected biological products on broad mite

Mitsui Chemicals America INC. 2017. Dinotefuran.https://www.mitsuichemicals .com/dinotefuran.htm

Palevsky E, Soroker V, Weintraub P, Mansour F, Abo-Moch F \& Gerson U. 2001. How species-specific is the phoretic relationship between the broad mite, Polyphagotarsonemus latus (Acari: Tarsonemidae), and its insect hosts? Experimental and Applied Acarology 25:217-224. doi: 10.1023/A:101064531 5630

Neal JW Jr, Buta JG, Pittarelli GW, Lusby WR \& Bentz JA. 1994. Novel sucrose esters from Nicotiana gossei: effective biorationals against selected horticultural insect pests. Journal of Economic Entomology 87:1600-1607

cornell.edu. 2017. Registration of Vectra 3D (EPA Reg. No. 83399-6) Containing the Active Ingredient Dinotefuran.Chemical Code: 044312.http://pmep.cce.c ornell.edu/profiles/insectmite/ddtfamphur/dinotefuran/dinotef_reg_1207.pdf

Sarwar M. 2015. The killer chemicals for control of agriculture insect pests: The botanical insecticides. International Journal of Chemical and Biomolecular Science 1:123-128

Senrung Al, Singh S, Sharma S, Bhutia TN \& Singh AK. 2014. Effect of Murraya koenigii extracts on feeding and ovipositional response of Spodoptera litura (Fab.) (Lepidoptera:Noctuidae) Journal of Entomology and Zoology Studies 2: 27-31

Simmons AM and Jackson DM. 2000. Evaluation of foliar applied insecticides on abundance of parasitoids of Bemisia argentifolii (Homoptera: Aleyrodidae) in vegetables. Journal of Entomological Science 35:1-8

Thodsare NH, Rajesh PB \& Srivastava RP. 2014. Bioefficacy of Murraya koenigii oil against Spilosoma obliqua and Spodoptera litura. Journal of Entomology and Zoology Studies 2:201-205

Ujjan AA and Shahzad S. 2012. Use of entomopathogenic fungi for the control of mustard aphid (Lipaphic erysimi) on canola (Brassica napus L.) Pakistan Journal of Botany 44: 208-2086

Van Leeuwen T, Vontas T \& Tsagkarakou A. 2009. Mechanisms of acaricide resistance in the two-spotted spider mite Tetranychus urticae. In Ishaaya I and Horowitz AR (eds) Biorational control of arthropod pests (pp347-393). Springer, Dordrecht

Venzon M, Rosado MC, Molina-Rugama AJ, Duarte VS, Dias R \& Pallini A. 2008. Acaricidal efficacy of Neem against Polyphagotarsonemus latus (Banks) (Acari: Tarsonemidae). Crop Protection 27:869-872. doi:10.1016/j.cropro. 2007.10.001

Vey A, Hoagland RE \& Butt TM. 2001. Toxic metabolites of fungal biocontrol agents. In Butt TM, Jackson CW \& Magan N (eds) Fungi as Biocontrol Agents (pp311346). $\mathrm{CABI}$, Publishing, Wallingford 